\title{
Vergi Planlaması Temelinde Kamu Yararı: Kurumlar Vergisi Üzerine Teorik Bir Yaklaşım
}

\author{
Abdullah Burhan BAHÇE* Öner GÜMÜŞ**
}

\begin{abstract}
$\ddot{O} Z$
Devlet vergi ile ilgili yükümlülükleri mükelleflere uyguladiğında bunu bir planlama ile yapmaktadır. Bu plan ise belirli ölçütler dâhilinde uygulamaya konulmaktadır. Söz konusu vergi planlamasının toplumsal faydayı gözetecek şekilde yapılması gerekmektedir. Nitekim toplumsal faydanın temelinde kamu yararının yattı̆̆ planlamasının başlangıç aşamasında kamu yararı unsurunun ön planda tutulması gerekmektedir. Türk vergi sistemine vergi planlaması açısından bakıldı̆̆ında kurumlar vergisinin hala vergilendirilebilir bir potansiyele sahip olduğu görülmektedir. Bununla birlikte devlet, kurumlar vergisi oranların yükseltecek bir vergi planlaması yaptı̆̆ında ciddi bir tepkiyle karşılaşabilmektedir. Dolayısıyla devlet kamu hizmetleri alanında işletmelerin payını daha fazla arttırarak bu muhalefeti azaltabilecektir. Ayrica kurumlar vergisinden elde edilen gelirler bir transfer harcamasi yoluyla bireylerin harcanabilir gelirini yükseltebilecektir. Buna ek olarak, gelir vergisi mükelleflerinin sayısı kurumlar vergisi mükelleflerinden daha fazladır. Dolayısıyla siyasi iktidar bu yolla oy maksimizasyonunu da gerçekleştirebilecektir. Bu çalışmada, bu perspektiften faydalanılmak suretiyle vergi planlamasinda vergilemede eşitlik, adalet, kesinlik ve belirlilik ilkelerine uyularak ve iktisadi etkinliğin sağlanarak kamu yararı unsuruna varılabileceği sonucuna ulaşılmıştır.
\end{abstract}

Anahtar Kelimeler: Vergi planlaması, kamu yararı, iktisadi etkinlik, kurumlar vergisi.

Jel Sinıflandirması: H21, H25, H53, D61.

\section{Public Interest on the Basis of Tax Planning: A Theoretical Approach on Corporate Income Tax}

\begin{abstract}
When applying the liabilities related to tax on taxpayers, the state does this with a plan. And this plan is entered into force by obvious criteria. The tax planning should be done by considering the social benefit. Hence, it can be stated that public interest lies on the foundation of social benefit. In other words, the factor of public interest should be prioritized at the beginning level of tax planning. When looked Turkish tax system in terms of corporate tax, it is seen that corporate tax still has a potential for taxation. However, when state makes tax planning by increasing the rate of corporate tax, it can meet a serius opposition. Thus, the state can relieve this opposition by increasing the share of businesses in the scope of public services. Also, the incomes obtained by corporate tax can increase the disposable incomes of individuals as transfer expenditures. In addition to this, the number of taxpayers of income tax are more than taxpayers of corporate tax. Accordingly, political power can realize the vote maximization by this way. In this study, by using this perspective, it is concluded that the factor of public interest can be reached by obeying the taxation principles of fairness, equity, accuracy and certainty and by providing economic efficiency.
\end{abstract}

Key Words: Tax planning, public interest, economic efficiency, corporate tax.

Jel Classification: H21, H25, H53, D61.

\footnotetext{
* Yrd. Doç. Dr., Dumlupınar Üniversitesi İiBF Maliye Bölümü, abdullah.bahce@dpu.edu.tr.

*** Arş. Gör., Dumlupınar Üniversitesi İ̈BF Maliye Bölümü, oner.gumus@dpu.edu.tr.
} 


\section{GİRIŞ}

Vergi politikasının içerisinde etkin olan unsurlardan birisi de vergi planlamasıdır. Bununla birlikte diğer değişkenleri de hesaba katmadan yapılacak bir vergi planlaması kamu yararını zedeleyebilmektedir. Dolayısıyla vergi planlamasının başlangıcında kamu yararına olumlu etki edecek unsurların dikkate alınması gerekmektedir.

Bu kapsamda çalışmada vergi planlamasının yöntemlerinden ziyade, bu yöntemlerden önce kamu yararının sağlanması üzerinde durulmuştur. Bunun sebebi vergi planlamasında hangi yöntem kullanılırsa kullanılsın temelinde toplumsal faydanın olmadığı bir vergi planlamasının zaman ve refah açısından bir kayba sebep olmasıdır. Ayrıca konu çoğunlukla kamu açısından ele alınmıştır.

$\mathrm{Bu}$ bağlamda ilk olarak devlet ve işletmeler açısından vergi planlaması konusu teorik olarak irdelenmiştir. Bu kapsamda devletin ve işletmelerin vergi planlamasında hangi noktada durdukları incelenmiştir. Ayrıca kamunun vergi cezası kapsamında neler öngördüğü ve işletmelerin buna karşın kullandığı metotlar da bu çerçevede ele alınmıştır.

İkinci husus kamu yararının hukuki ve iktisadi anlamları detaylı olarak ele alınmıştır. Keza kamu yararının olmadığı bir durumda herhangi bir mali unsura ilişkin yapılan planlamalar bir anlam ifade etmeyecektir. Bu noktada kamu yararının özellikle iktisadi anlamı üzerinde durulmuştur. Bunun sebebi de toplumda meydana gelen ekonomik etkinsizliğin hukuki anlamda kamu yararı ile nasıl bir ilişki içerisinde olduğunu ortaya koymaktır.

Son olarak vergileme ilkeleri, kamu yararı ve vergi planlaması arasındaki bağ irdelenmiş ve bu kapsamda politik olarak dengede bulunan bir vergileme durumu kurumlar vergisi ve gelir vergisi açısından ele alınmıştır. Bu çizgide vergi planlamasına başlamadan önce kamu yararının gözetilmesi amacıyla iktisadi ve mali önerilerde bulunularak çalışma sonlandırılmıştır.

\section{VERGI PLANLAMASI}

Kamu içerisinde en önemli ve en temel gelir kaynağını vergiler teşkil etmektedir. Devlet egemenlik gücüne dayanarak bünyesindeki bireylerden çeşitli kıstas ve kurallar çerçevesinde iktisadi değerler elde etmektedir. Söz konusu iktisadi değerler vergi olarak tanımlanmaktadır. Vergiler ayrıca karşılıksız ve sağlam olma özelliklerine de sahip bir kamu geliridir. Bu kamu geliri fiili ekonomik faaliyetler üzerinden alınmaktadır. Söz konusu faaliyetler servet, tüketim, tasarruf ve üretim faaliyetleridir. Adı geçen faaliyetler ekonominin periyodik süreçlerine göre değişim gösterebilmektedir. Dolayısıyla bu periyodik süreçlerin içinde bulunduğu koşullar bakımından vergi gelirlerinde artışlar veya azalışlar gözlenebilmektedir (Altay, 2015: 123). Bu perspektiften bakıldığında verginin de konjonktüre uygun hareket edebilmesi için bir planlamaya sahip olması gerekmektedir.

İyi bir vergi planlamasının gerçekleştirilebilmesi için iyi bir vergi sistemi tasarlanmalıdır. Bu bağlamda iyi bir vergi sistemi belirli özeliklere sahip olmalıdır.

İyi bir vergi sisteminin özellikleri şunlardır (Peter vd., 2002: 113-115): 
- Eşitlik: Vergi sisteminde eşitlik hususunda kabul gören ilke mali güç ilkesidir. Bu ilke uyarınca vergi yükünün dağılımı mükelleflerin mali gücüyle orantılı olmalıdır.

- Etkinlik: Vergileme şeklinin ekonomideki kısıtlı kaynakların etkin bir dağılımını teşvik etmesi gerekmektedir.

- Basitlik: Basit bir vergi sistemi için uyum ve yönetim maliyetlerinin minimize edilmesi gerekmektedir

Vergi planlamasında eşitlik, etkinlik ve basitlik unsurlarının olması vergi planlamasının zemininin daha sağlam olmasını sağlayacaktır. Bu kapsamda vergi planlamasının tanımının yapılması daha etkin bir projeksiyon elde edilebilmesine olanak taniyacaktır.

Şişman (2003) vergi planlamasını işletmelerin kanunlar çerçevesinde kullanabilecekleri haklar olarak tanımlamıştır. Burada vergiden kaçınma durumu söz konusudur. Bununla birlikte yasadışı bir şekilde de vergi planlaması yapmak mümkündür. Ancak ortaya çıkan husus vergi kaçakçılığı olarak nitelendirilmektedir (Şişman, 2003: 33).

Bir diğer açıdan tanımlanacak olduğunda vergi planlaması, bir takvim yılı içerisinde vergi avantajını maksimum kılmak veya ödenecek olan vergiyi minimize etmek için vergisini zamanında tahakkuk ettirip ödeyen mükelleflerce gerçekleştirilen ve temkinli bir biçimde tasarlanan, önceden ve geleceğe yönelik olarak öngörülen genel işlemler, araştırma çabaları, süreçler ve düzenlemeler olarak ifade edilebilmektedir (Eroğlu, 2014: 4). Başka bir ifadeyle vergi planlaması daha geniş bir şekilde iyi bir vergi sisteminde bulunması gereken eşitlik, etkinlik ve basitlik özelliklerini içinde barındıran, yasal veya gayri yasal bir şekilde önceden ve geleceğe dönük olarak tasarlanan periyodik bir mali düzenleme olarak tanımlanabilir.

Vergileme süreci birbiriyle çatışan menfaatleri kapsamaktadır. Devlet kendi vatandaşlarınca kolektif olarak karar verilen kamu sektörü faaliyetlerini finanse etmek zorundadır. Bu esnada vatandaşlar bireysel olarak kanun tarafından sağlanan çatı çerçevesinde mümkün olduğunca az vergi ödemeye çabalarlar. Söz konusu koşullar çeşitli problemler ortaya çıkardığı gibi çeşitli firsatlar da sunmaktadır. Çevreye ilişkin vergileme ve kurumların vergilendirilmesine ilişkin bazı kurallar yasama önlemlerinin birçok anlamda kurumların ve bireylerin davranışlarında bir değişiklik elde etmek için vergilerini düşürme arzularını kullanmak maksadıyla nasıl uğraştığına ilişkin örnekler sunmaktadır (Agell vd., 1998: 24). Dolayısıyla devlet vergi planlaması yaparken söz konusu hususları dikkate alarak hareket etmelidir.

İşletmeler açısından ele alındığında ise vergi planlamasının amacının firmanın kendi değerinin maksimize edilmesi ile belirlendiği dikkati çekmektedir. Vergi planlamasının odak noktası opsiyonel olarak firmaların yönetim stratejisinde ve genel yatırımlarında dikkate alınması gereken bütün hedeflerine uygun olması gerekmektedir. Optimal çözüm ise farklı seçenekler mevcut olduğu takdirde en yüksek çıkarı sağlayan çözümdür. Firmalar bunu genel olarak ele almalı, akıllıca ölçmeli ve ayrıca vergi planlamasının amacı ile firmanın bütününün kalkınma 
hedefleri arasındaki tutarlılığa dikkat etmelidir. Ancak firma vergi planlamasının amacına ulaşması için firmanın yönetim amacını göz ardı edemez. Firma yalnızca bu yolla vergi planlamasının doğasını ve ruhunu yakalamakta; ayrıca yine bu yolla vergi planlamasını kendi kalkınmasına yardımcı olan etkin bir araca dönüştürebilmektedir (Gao vd., 2011: 369).

Bireyler açısından da vergi planlamasında dikkate alınacak iki unsur enflasyon ve vergilerdir. Bununla birlikte enflasyon bireylerin kontrolü dışında yer alırken, etkin bir vergi planlaması açısından bireyler proaktif bir rol oynayabilmektedirler (Fevurly, 2013: 155).

\section{VERGI PLANLAMASININ AKTÖRLERİ}

Vergi planlamasının aktörleri bireyler, kurumlar ve devlet olarak ifade edilebilmektedir. Bununla birlikte bireyler, işletmeler ve devlete göre daha kısıtlı bir etkiye sahiptirler. Dolayısıyla vergi planlamasının aktörleri olarak bireylerden ziyade işletmeleri ve devleti temel almak daha gerçekçi öngörülere ulaşılmasını sağlayabilecektir.

\section{A. Vergi Planlamasinda Devlet}

Üzerinde en çok mutabık kalınan ve en az tartışmalı maliye politikası hedefleri nispi fiyat istikrarıyla birlikte tam istihdama ulaşmaktır. Buna ek olarak daha spesifik amaçlar da öne sürülmüştür. Bu amaçlardan bazıları kısmi olarak da olsa uygulama alanı bulmuştur. Söz konusu amaçlar tasarrufları ya da yatırımları artırmak; ev sahibi olmayı teşvik etmek, refahın yeniden dağılımı veya en azından gelir düzeylerindeki farklılıkları indirgemek gibi makro özelliklere sahiptir. Diğer amaçlar ise daha yüzeyseldir. $\mathrm{Bu}$ yüzeysel kötüleşen coğrafi bölgelerin hedeflenmesi, yerel bir denizcilik endüstrisinin desteklenmesi ile doğalgaz ve petrol rezervleri kalkınmasının teşviki gibi hususları kapsamaktadır. Mükelleflerce belirli fiillerin teşvik edilmesi için tasarlanmış herhangi bir vergi sunumu mükellefler arasında adalet konusunu gündeme getirmektedir (Oliver, 2004: 27). Dolayısıyla vergi planlamasında gözetilmesi gereken hususlardan biri adalet olgusudur.

Vergide eşitlik kavramı kurulu düzenin bir bakıma destekleyicisi olan ahlaklılık, inançlar, değerler, tutumlar vb. olgulara ilişkin tüm sistemin bir parçasıdır. Vergi eşitliği tartışmasız bir şekilde iyi bir olgu olarak görülmektedir. Eşitlik kavramından yola çıkılacak olursa, eşitlikçi bir devletin etik olarak veya işlevsel olarak kusursuz olduğu herkesin kabul ettiği bir olgudur. Eşitlik olgusu, iyi bir vergi sisteminin veya iyi bir vergi politikasının özelliklerinden biri olarak görülmektedir (Infanti, 2009: 62). Bu bakımdan vergi planlamasında eşitlik ilkesinin de gözetilmesi önemli bir husus olarak ortaya çıkmaktadır.

Örneğin, emlak vergisine ilişkin bir hesaplamanın aşağıda belirtildiği şekilde yapıldığı varsayıldığında (1) no'lu eşitlikteki gibi bir durum ortaya çıkabilir (Gravelle and Maguire, 2007: 100):

$$
\begin{aligned}
& t \times\left(A^{t}-E^{s}-E^{b}\right)=A^{n b} \\
& A^{t}=A^{b}+A^{n b}
\end{aligned}
$$

Burada $t$ emlak vergisi oranını; $\mathrm{A}^{\mathrm{t}}$ arazi üzerindeki tüm varlıkların toplam değerini; $A^{\mathrm{nb}}$ işletme dışı varlıkların toplam değerini; $A^{\mathrm{b}}$ arazi üzerindeki işletme 
varlıklarının toplam değerini; $\mathrm{E}^{\mathrm{s}}$ standart arazi vergisi muafiyet değerini ve $\mathrm{E}^{\mathrm{b}}$ işletme varlık muafiyetini göstermektedir (Gravelle and Maguire, 2007: 100). Bu noktada da uygulanan verginin oran1, kime uygulanacağı, ne kadar ve nasıl uygulanacağı ifade edilmiştir. Bir başka deyişle vergi planlamasında yer alan unsurların net bir şekilde ifade edilmesi gerekmektedir.

\section{B. Vergi Planlamasında İşletme}

İşletme emek ve sermaye faktörlerini kullanarak bireyler için üretim yapmak ve brüt kazancından işletmede iştiraki bulunan kişilere gelir sağlamak amacıyla kurulmaktadır. Bu sebeple vergi, işletmeler için bir transfer harcaması niteliğinde olduğundan işletmeler kuruluşlarında, faaliyetlerini sürdürdügünde ve faaliyetlerini sonlandırdığında vergileri önemli bir faktör olarak dikkate almak zorundadir (Bildirici, 1986: 17).

İşletmeler; bireysel işletme, adi ortaklık, kolektif ortaklık/şirket, komandit ortaklık/şirket, limited veya anonim şirket şekillerinden herhangi biriyle kurulabilmektedir. Bu işletme şekillerinin seçilmesinde uygulanan ve gelecekte uygulanması düşünülen vergi oranları, işletme sahibine ödenen ücretlerin gider yazılması veya gider olarak kabul edilmemesi, sermaye yapısı, ücret dışında ortaklara sağlanan menfaatler, kar dağıtım politikası veya işletme sahiplerinin veya ortaklarının işletme dışında herhangi bir kazanç elde edip etmemesi gibi hususlar önemli bir rol oynamaktadır (Bildirici, 1986: 14). Böyle bir vergi yapısı içerisinde işletmeler çeşitli idari ve kontrol mekanizmaları ile vergi ödememe yönünde içgüdüsel bir eğilim gösterebilmektedirler.

İşletmeler için ifade edilen idari ve kontrol mekanizmasındaki unsurlar uyum prensibi ve koruma prensibi olarak ifade edilir. Koruma prensibi, işletmecinin işletmesi üzerinde gücünü, kazanç payını ve fiili durumunu koruma isteğidir. Uyum prensibi ise yönetim şeklinin rekabet koşullarına ve yeni olanaklara ayak uydurması ile ilişkilidir (Bildirici, 1986: 12). Bu doğrultuda vergiden kaçınma ve vergi kaçırma kavramlarına değinmek gerekmektedir.

Vergi yasalarına aykırı davranmayan işletmelerin yapacağı yasal faaliyetler neticesinde daha az vergi ödenmesi işletmelerin vergiden kaçınması anlamına gelmektedir (Erdem vd., 2012: 175). İşletmeler beyan etmesi gereken vergi matrahlarını beyan etmedikleri takdirde ise bu durumda vergi kaçakçılığı ortaya çıkmaktadır (Erdem vd., 2012: 177). Bu noktada işletmeler uyum prensibi ile yeni ortaya çıkan mali koşulları dikkate alarak vergiden kaçınabilmektedir. Böylelikle işletmeler yapacağı vergi planlaması ile bir yandan idari düzeni bozmayacak, öte yandan kar maksimizasyonlarını gerçekleştirecek bir konuma gelebileceklerdir. Bununla birlikte işletmeler koruma prensibi kapsamında mali koşulların yasal sınırını aştığı takdirde vergi kaçakçılığı ortaya çıkmaktadır.

Vergi kaçakçıllı̆ı içerik itibarıyla ekonomik, sosyal, mali ve ahlaki düzeni bozmakta ve ayrıca devletin vergilendirme alanındaki yetkisini de işlevsiz bir hale getirmektedir. Bunun neticesinde de vergi önünde eşitlik ilkesi ortadan kalkmaktadır. Buna ek olarak, vergi kaçakçılığı sosyal devletin fonksiyonlarını zedeleyerek, söz konusu fonksiyonların tersine işlemesine sebep olmaktadır (Devrim, 2002: 257). 
Vergi kaçakçıllı̆ı suçu işlendiğinde devlet bazı yaptırımlar uygulamaktadır. Vergi kaçakçılığı olayları aynı zamanda vergi ziyaı kabahatinin ağır nitelikli fiilleridir. Söz konusu fiiller ve devletin öngördüğü cezalar ise şu şekilde ifade edilebilir (Şenyüz vd., 2012: 229):

- Hesap ve muhasebe hileleri yapılması (normal zedeleyen fiil/18 aydan 3 yıla kadar hapis cezasi)

- Gerçek olmayan kişiler adına hesaplar açılması (normal zedeleyen fiil/18 aydan 3 yila kadar hapis)

- Çift defter tutulması (normal zedeleyen fiil/18 aydan 3 y1la kadar hapis)

- Defter, kayit ve belgelerin tahrif edilmesi veya gizlenmesi (normal zedeleyen fiil/18 aydan 3 yıla kadar hapis)

- Yanıltıcı belge düzenlenmesi veya kullanılması (normal zedeleyen fiil/18 aydan 3 yila kadar hapis)

- Defter, kayıt ve belgelerin yok edilmesi (çok ağır zedeleyen fiiller/3 y1ldan 5 yıla kadar hapis)

- Defter sayfalarının kopartılarak yok edilmesi (çok ağır zedeleyen fiiller/3 yıldan 5 yıla kadar hapis cezasi)

- Sahte belgelerin düzenlenmesi veya kullanılması (çok ağır zedeleyen fiiller/3 y1ldan 5 yıla kadar hapis)

- Maliye Bakanlığı ile anlaşmalı olmayan matbaaların belge basması ve bu belgelerin bilerek kullanılması (ağır zedeleyen fiil/ 2 yıldan 5 yıla kadar hapis)

Burada dikkati çeken nokta hapis cezalarının en az 18 ay olmasıdır. Verilecek ceza bir yılın üzerinde olduğu için cezanın paraya çevrilme olanağı da bulunmamaktadır (Şenyüz vd., 2012: 230). Normal koşullarda borcunu ödemeyen bireylerin özgürlüğünden alıkonulması modern hukuk anlayışının dışında bir olgudur. Ancak kamu hukukundan kaynaklanan vergi yükümlülüğünde ortaya çıkan durum biraz daha farklıdır (Çomaklı ve Ak, 2013: 39). Çünkü vergi bir kamu geliri olduğu için söz konusu gelirin elde edilmesinde kanun koyucu bir kamu yararı görmektedir. Dolayısıyla işletmeler koruma prensibini vergi planlamasında uygularken kanunları ihlal etmemelidir. Aksi takdirde anayasal bir hak olan özgürlük unsurundan mahrum kalma ihtimalleri doğabilecektir.

\section{KAMU YARARININ HUKUKİ VE İKTISSADİ KAPSAMI}

Kamu yararı kavramı literatürde daha çok hukuki anlamıyla incelenmektedir. Ayrıca kamu yararı ile toplum yararı kavramlarının birbiri ile aynı anlama gelmediğini ifade eden görüşler de mevcuttur ${ }^{1}$. Ancak Saraçoğlu (2014) söz konusu kavram ile ilgili şunları ifade etmektedir: "Kavramın çok işlevli ve soyut yapısl, ona esneklik kazandırmakta, somut koşullara göre belirlenmesine neden olmakta ve her zaman kullanılmasını sağlamaktadır".

\footnotetext{
${ }^{1}$ Detaylı bilgi için bkz. Doğanay, 1974: 5-6,

https://wiki.zirve.edu.tr/sandbox/users/alptekin.aktalay/weblog/bede2/attachments/eed3e/Kamu\%20yarar1\%20mi marlık\%20dergisi.pdf?sessionID=190148cd32475de0a28dc580d66c590be4060236 (Erişim Tarihi: 28.03.2016). 
Dolayısıyla kavramın hukuki içeriğinin yanında iktisadi içeriğinin de olduğu öne sürülebilmektedir. Bu perspektiften bakıldığında ekonomide ortaya çıkacak dara kaybı durumun iktisadi yönünü teşkil ederken, söz konusu dara kaybının ortadan kaldırılarak kamu yararının sağlanması ise durumun hukuki yönünü teşkil etmektedir.

\section{A. Hukuki Açıdan Kamu Yararı}

Kamu yararının ortaya çıkması için yürütülmesi gereken etkinlikler kamu hizmeti olarak adlandırılmaktadır. Bir diğer ifadeyle kamu hizmetlerine duyulan ihtiyacın giderilmesi halinde kamu yararı sağlanabilmektedir (Giritli vd., 2012: 1050). Dolayısıyla kamu yararı kavramının ruhunu anlayabilmek için öncelikle kamu hizmeti kavramı irdelenmelidir.

Kamu hizmeti kavramı maddi ve organik unsurlara sahiptir. Organik unsura sahip olan kamu hizmeti kavramında kamu hukuku tüzel kişileri veya bu tüzel kişilerin belirlediği aktörler kamu hizmetlerini görmektedirler. Kamu hizmeti kavramının maddi unsurunda ise kamu yararı içeren faaliyetlerin toplumsal ihtiyacı karşılaması söz konusudur (Yıldırım vd., 2012: 638). Buradan hareketle kamu yararı kamu hizmetinin maddi unsurunda doğrudan ortaya çıkarken, kamu hizmeti kavramının organik unsurunda dolaylı olarak ortaya çıkmaktadır.

Kamu hizmetinin maddi ve organik unsurları çerçevesinde kamu hizmetlerinin özellikleri şu şekillerde ifade edilebilmektedir (Atay, 2014: 587-589):

- Kanuni sınırların içerisinde toplumsal bir ihtiyacın giderilmesi için tesis edilir,

- Özel hukuk kişileri tarafından da görülebilir,

- Kamu yararını gerçekleştirmek amacıyla yapılır,

- Kamu yararı kamu hizmetinin ulaşabileceği en son noktadır. Bu nedenle kamu hizmetlerinden faydalananlardan bedel istendiği durumlarda kar maksimizasyonu amacı güdülmemesi gerekir. Bununla birlikte ticari ve sınai faaliyetler bu husustan müstesnadır,

- Kamu hizmetlerinde özel hukuk hükümlerinin de geçerli olabileceği durumlar söz konusudur,

- Hizmet ifa edilirken kamu tüzel kişisi kamu gücünden kaynaklanan üstünlük ve imtiyazları kullanır,

- Kamu hizmetlerinin hızlı bir şekilde görülmesi gerekmektedir. Ayrıca verimliliği ölçülemez. Bu nedenlerden ötürü de arzını piyasa fiyatları belirlemez.

Kamu hizmetlerinin sahip olduğu özellikler yanında söz konusu hizmetlere egemen olan ilkeler de mevcuttur. Bu ilkeler süreklilik (kesintisizlik) ve düzenlilik ilkesi, değişkenlik (uyarlama) ilkesi, nesnellik ve eşitlik ilkesi ile bedelsizlik (meccanilik) ilkesidir (Günday, 2011: 334-336; Sancakdar, 2012: 510):

- Süreklilik (Kesintisizlik) ve Düzenlilik İlkesi: Kamu hizmetlerinin yürütülmesi ile giderilecek olan toplumsal ihtiyacın kendisini hissettirdiği her an kamu hizmetinin süreklilik ilkesi daha belirgin 
olarak ortaya çıkmaktadır. Düzenlilik ile kastedilen ise kamu hizmetlerinin işleyişindeki düzenliliktir (Günday, 2011: 334).

- Değişkenlik (Uyarlama) İlkesi: Kamu hizmetlerinin değişen ve gelişen koşullar ile teknik verilere uyarlanması değişkenlik ilkesinin özelliğidir (Günday, 2011: 335).

- Nesnellik ve Eşitlik İlkesi: Kanunların veya diğer hukuki işlemlerin belirlediği nitelik ve koşullara sahip olan bireylerin hepsine aynı hukuki muamelenin yapılması ile ilgilidir (Sancakdar, 2012: 510).

- Bedelsizlik (Meccanilik) İlkesi: Şehir içi otobüslerin öğrencilere indirimli olması örneğinde olduğu gibi, kamu hizmetlerinin maliyetini karşılayacak bir bedel olmalıdır. Bir başka deyişle maliyet ve kardan oluşan fiyat kamu hizmetlerinde söz konusu değildir. Bu durum meccanilik ilkesinin bir yansımasıdır (Sancakdar, 2012: 510).

$\mathrm{Bu}$ ilkelerden ayrı olarak laiklik ilkesi de kamu hizmetlerinin bir diğer özelliği olarak kabul edilmektedir. Laiklik ilkesi nesnellik ilkesinin bir uzantısıdır. Burada hizmeti sunan kamu personeli ve hizmeti görülen vatandaş olmak üzere iki aktör söz konusudur. Kamu personeli açısından bakıldığında, kamu personelinin dinsel inançlarını bir yana bırakarak kamu hizmetini yerine getirmesi gerekmektedir. Kamu hizmetlerinden faydalanan vatandaşlar açısından ise laiklik ilkesinin mutlak bir şekilde uygulanıp uygulanmayacağ 1 tartışmalı bir konudur (Gözler, 2011: 305).

Kamu hizmetlerinin görülme aşamasında devlet idari bir kararla bunları uygulamak durumundadır. Bir diğer ifadeyle idari kararın icrailik özelliği bulunmaktadır. $\mathrm{Bu}$ özellik idareye özel kişilerle ilişkileri esnasında önemli avantajlar sağlamaktadır. Söz konusu özellik vasıtasıyla idare kendi iradesini kullanmak suretiyle almış olduğu kararları özel kişilere dikte ettirme imkânına kavuşmakta ve bu nedenden ötürü de icrailik özelliğinin temelinde yatan etken kamu gücü olarak ortaya çıkmaktadır. Devletin kamu gücüne sahip olması ise kamu yararı unsurunu ortaya çıkarmaktadır (Gözler, 2003: 567).

Bireyler kamu yönetiminin çeşitli alanlarına farklı düzeylerde katılmak suretiyle kamuya katkıda bulunurlar. Söz konusu katkı ile bireylerin kamu hizmetlerinden faydalanması arasında kural olarak bir oran bulunmamaktadır. İdare bireyler ve toplum arasında toplumdan yana tercihini kullanmaktadır. Başka bir deyişle bireysel çıkarlarla toplumun çıkarlarının çatıştığı bir durumda idare toplumsal çıkardan yana kendini taraf olarak göstermektedir. Buradaki amaç idarenin bünyesindeki bireylerin insanca yaşayabilmelerini sağlamaktır. Dolayısıyla idarenin üstlendiği bu görevler söz konusu amacın kapsamında görülmektedir. $\mathrm{Bu}$ amacın geneline bakıldığında ise genel amacın kamu yararı olduğu gözlenmektedir. İdarenin var oluş amacı da budur. İşte toplumsal ihtiyaçlardan ortaya çıkan kamu hizmetlerinin görülmesindeki temel amaç da bahsi geçen kamu yararıdır (Gözübüyük, 2007: 10).

Kamu yararı toplum temel alınmak şartıyla devletin bazen bireyi bazen de toplumu düşünen hareketlerde bulunduğu; niteliği üstün olan faydanın tercih edildiği, bireylerin kişisel yararlarının toplamı olmayan ve aynı zamanda bireylerin 
yararlarının dışında söz konusu bireylerle ilişkili olan yarar unsurunun bulunduğu bir olgu olarak tanımlanabilmektedir (Akyılmaz vd., 2012: 27-28). Ayrıca toplum için çok önemli olan ve kar amacı gözetilmeksizin idare tarafindan yürütülerek toplumun söz konusu hizmetlerden faydalandırılması da kamu yararı olarak tanımlanabilmektedir (Yıldırım, 2015: 128). Bu bağlamda kamu yararına atfedilen nitelikler şu şekillerde ifade edilebilir (Saraçoğlu, 2014: 24-25):

- Genel ve yararı soyut bir kavram olmas1,

- Mutlak ve bilimsel analize dayalı olmamas1,

- Soyut ve akıldışı bir kavram olması,

- Toplumun gelişimine, zamana ve ekonomik ve sosyal gelişmeye göre yorumlanmasi,

- Sınırlarının hukuku aşması,

- Durağan bir anlama sahip olmas1,

- Devletten devlete farkl11k arz etmesi,

- Farklı dönemlerde farklı anlamlara sahip olması,

- Siyasal görüşlere göre değişiklik ifade etmesi,

- Kanun koyucunun yetki sınırını oluşturması,

- Devletçilik geleneğinin temellerinin sağlamlaştırılmasında kullanilmasi.

Ayrica normlar hiyerarşisinde yerel olarak en üstte bulunan 1982 Anayasası'nın 43. maddesinde (kıyılardan yararlanma), 44. maddesinde (toprak mülkiyeti), 45. maddesinde (tarım, hayvancılık ve bu üretim dallarında çalışanların korunmas1), 46. maddesinde (kamulaştırma) ve 47. maddesinde (devletleştirme ve özelleştirme) kamu yararının gözetilmesi öngörülmüştür.

\section{B. İktisadi Açıdan Kamu Yararı}

Kamu yararının özelliklerinden hareketle kamu yararının iktisadi bir yönü olduğu da aşikârdır. Söz konusu olgunun iktisadi yönü ise toplum refahının artması ya da azalması bağlamında açıklanabilir. Bu da dara kaybı olgusunun açıklanmasını gerektirmektedir.

Dara kaybı üretici veya tüketici artığındaki bir kayıptan dolayı refah düzeyinde ortaya çıkan net azalmadır. Burada üretici veya tüketici artığındaki bir kayıp diğer tarafın piyasa dengesini değiştirecek bir eylem neticesinde elde edeceği kazançla karşılanamamaktadır (Perloff, 2007: 277). 
Grafik 1. Dara Kayb1

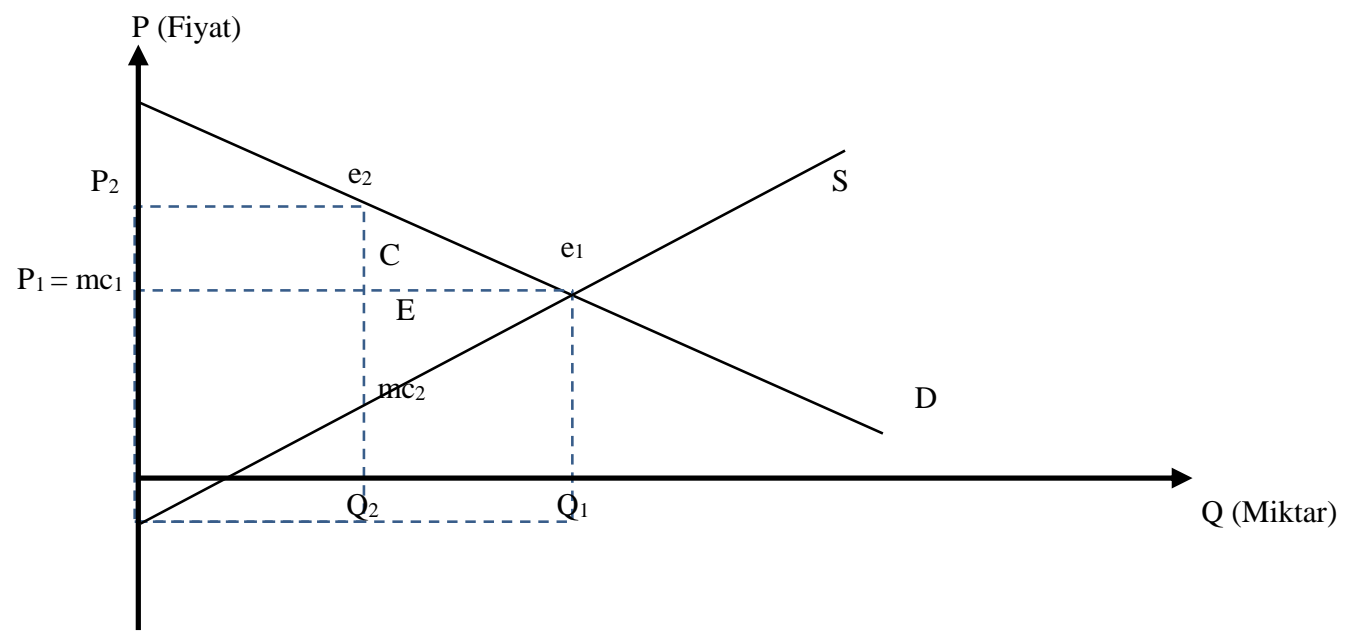

Kaynak: Perloff, 2007: 276'dan esinlenerek tarafımızca hazırlanmıştır.

Grafik-1 incelendiğinde denge noktası arz (S) ve talep (D) eğrilerinin kesiştiği $\mathrm{e}_{1}$ noktası olarak ortaya çıkmaktadır. Ancak verginin işletmeler için bir maliyet unsuru olduğundan hareketle, vergi oranlarında meydana gelecek bir artış örneğinde işletmelerde fiyatı yükseltme yönünde bir eğilim oluşturacaktır. Böyle bir durumda fiyat $\mathrm{P}_{1}$ 'den $\mathrm{P}_{2}$ düzeyine yükselecektir. Grafik-1'e bakıldığında fiyatta meydana gelen bir yükselme $\mathrm{C}+\mathrm{E}$ kadar bir dara kaybı meydana getirmiştir. Bir diğer ifadeyle refahta -C-E kadarlık bir azalma söz konusudur. Bu durumun bir diğer göstergesi de mal miktarının $\mathrm{Q}_{1}$ 'den $\mathrm{Q}_{2}$ 'ye doğru bir azalma göstermesidir. Dolayısıyla fiyatta meydana gelen yükselme toplum açısından bir refah kaybı oluşturacaktır.

Bu noktada dara kaybının az ya da fazla olmasında iktisadi belirleyicilerin varlığı söz konusudur. Bu belirleyiciler şunlardır (Mankiw, 2008: 165):

- Esnek Olmayan Arz: Arz eğrisi nispi olarak esnek olmayan bir hale geldiğinde, dara kaybı küçük boyutta ortaya çıkmaktadır. 
Grafik 2. Esnek Olmayan Arz

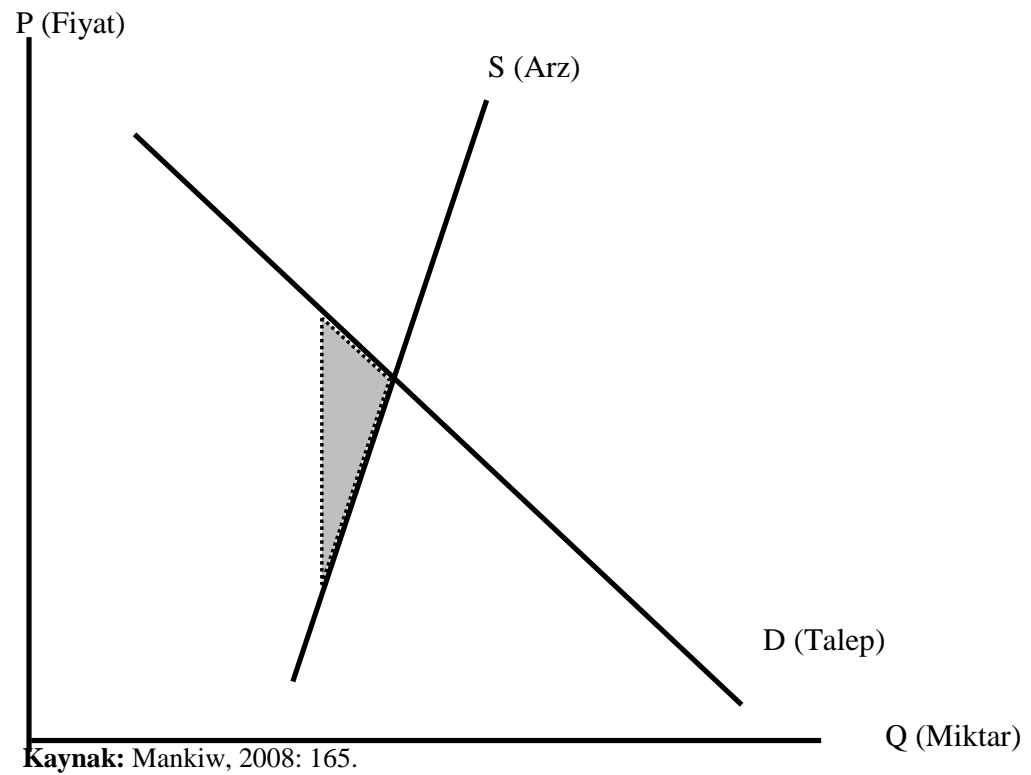

- Esnek Arz: Arz eğrisi nispi olarak esnek olduğunda, dara kayb1 büyük bir boyutta ortaya çıkmaktadır.

Grafik 3. Esnek Arz

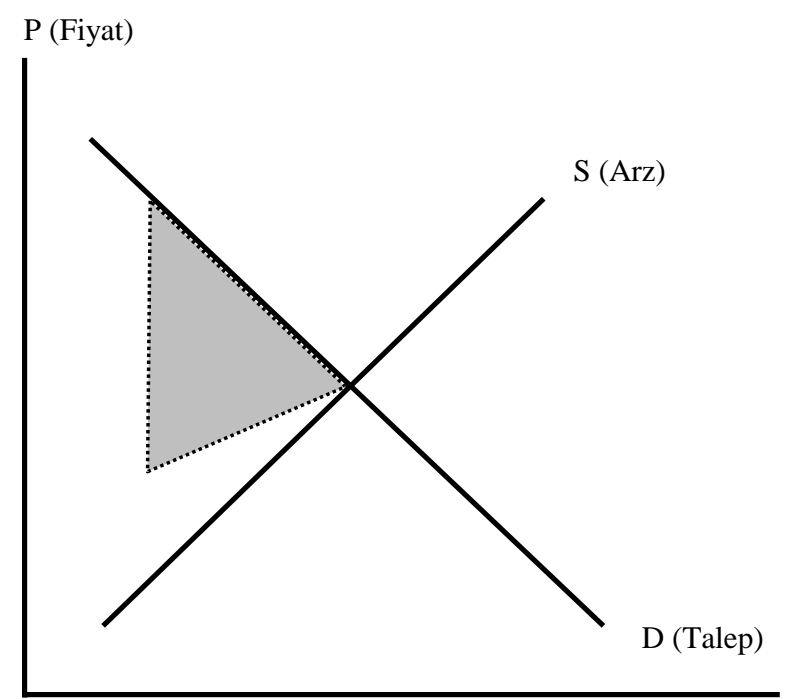

Kaynak: Mankiw, 2008: 165. 
- Esnek Olmayan Talep: Talep eğrisi nispi olarak esnek olmayan bir hale geldiğinde, dara kaybı küçük bir boyutta ortaya çıkmaktadır.

Grafik 4. Esnek Olmayan Talep

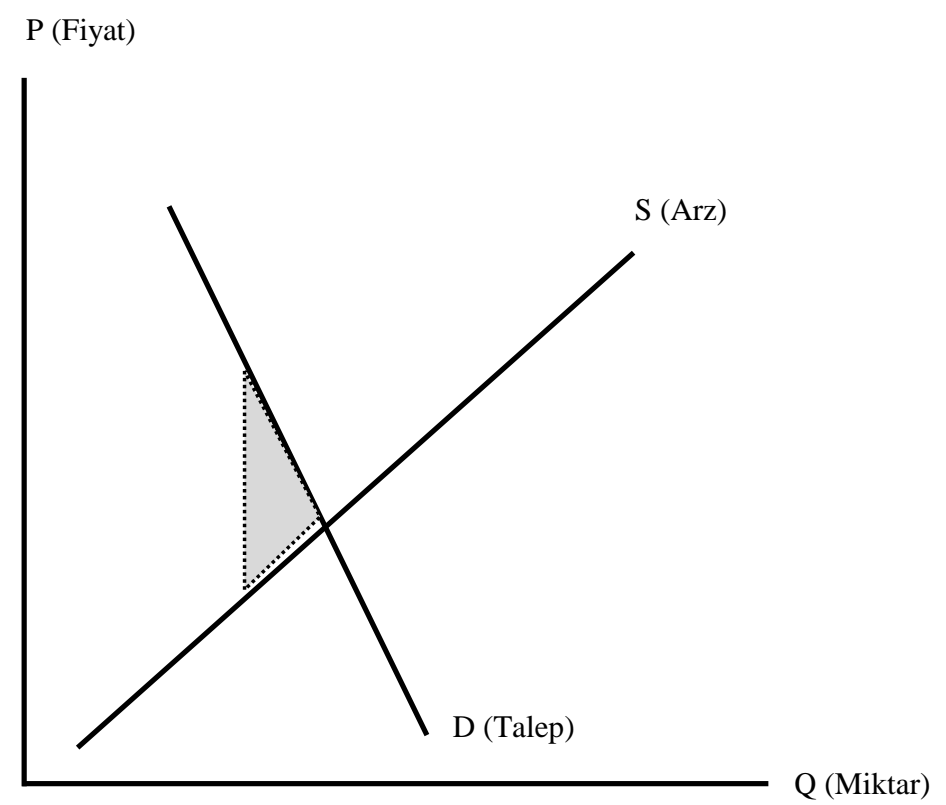

Kaynak: Mankiw, 2008: 165.

- Esnek Talep: Talep eğrisi nispi olarak esnek olduğunda, dara kaybı büyük bir boyutta ortaya çıkmaktadır. 
Grafik 5. Esnek Talep

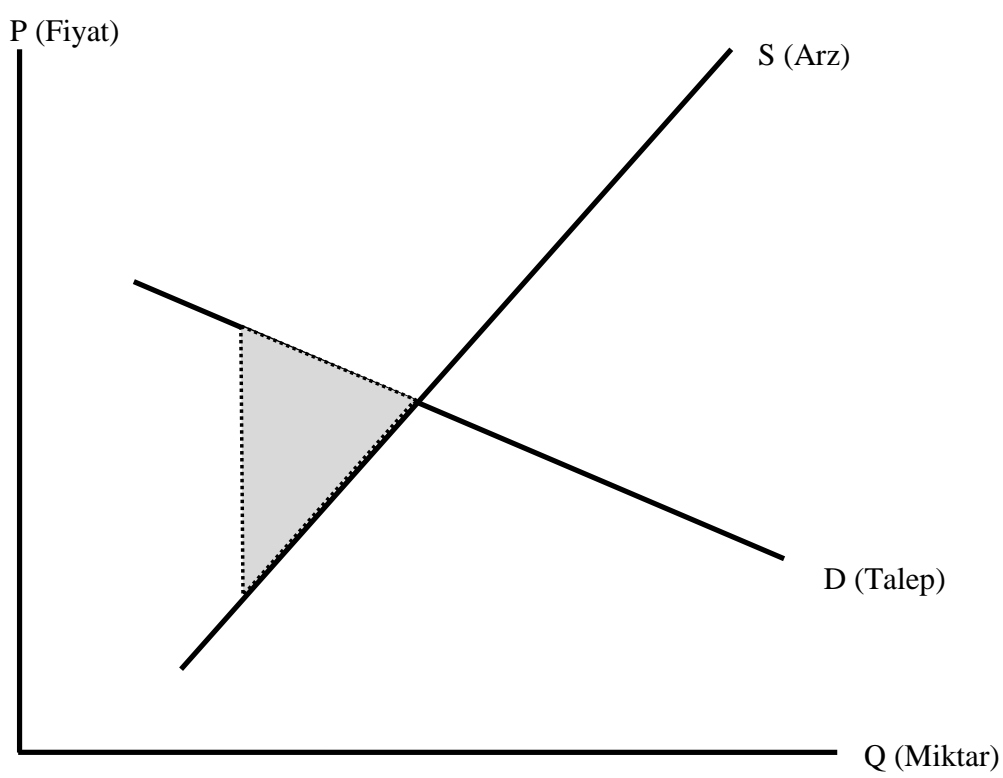

Kaynak: Mankiw, 2008: 165.

Dara kaybı piyasanın etkinlikten uzaklaşmasının bir ölçütü olarak görülmektedir (Parkin, 2010: 115). Bu bağlamda etkinliğin sağlanabilmesinin önündeki engeller ise fiyat ve miktar düzenlemeleri, vergiler ve sübvansiyonlar, dışsallıklar, kamu malları ve ortak kaynaklar, tekel ve yüksek işlem maliyetleridir (Parkin, 2010: 116). Söz konusu unsurların aşırı veya yetersiz kullanımı neticesinde aşırı üretim veya eksik üretim ortaya çıkar. Bu durum da refah seviyesinde bir düşüşe ve dolayısıyla dara kaybına yol açar. Bu olguların etkin kullanımı ise dara kaybının ortadan kalkmasını ve bu çerçevede kamu yararının sağlanması hususunu gerçekleştirecektir.

IV. VERGI PLANLAMASINDA KAMU YARARININ YANSIMALARI: VERGILEMEDE ADALET, EŞITTLİK, KESİNLİLIKK VE BELİRLILIIK İLKELERİ İLE İKTISADII ETKINLIK

Vergiler kamu idaresinde konumlanmış olan, bir ülkenin emek ve sermayesinin ortaya çıkarmış olduğu üretiminin bir parçasıdır ve her zaman ülkenin gelirlerinden veya sermayesinden yapılan nihai bir ödemedir (Ricardo, 1996: 105). Dolayısıyla bu ödemede birçok aktör bulunmaktadır. Bu açıdan bakıldığında devletin vergi planlamasinda vergileme ilkelerine uygun hareket edilmesi gerekmektedir. Bununla birlikte öncelikle vergi planlamasını uygulayacak kamu idaresinin özellikleri ile işletme yönetimlerinin özellikleri arasındaki farkların bilinmesi gerekmektedir. 
Tablo 1. Kamu Sektörü ve Özel Sektör Yönetimleri Arasındaki Farklılıklar

\begin{tabular}{|c|c|}
\hline Kamu Hizmetleri & Özel Sektör \\
\hline Kanuni düzenleme & Yönetim kurulu \\
\hline Ulusal ihtiyaçlar & Piyasa odaklı uyarılar \\
\hline Nispi olarak açık & Nispi olarak gizli \\
\hline Genel kamu ilgisi & Genellikle ve yalnızca hissedarların ilgisi \\
\hline Çoklu amaçlar- öncelikli olarak sosyal & $\begin{array}{c}\text { Basit amaçlar- öncelikli olarak hissedarların } \\
\text { çıarı }\end{array}$ \\
\hline Vergilerle finanse edilir & $\begin{array}{c}\text { İşlemsel getiriler, krediler ve finansal } \\
\text { piyasalarca finanse edilir }\end{array}$ \\
\hline Politik idareye karşı sorumlu & Hissedarlara karşı sorumlu \\
\hline $\begin{array}{c}\text { Performansın karmaşı ve tartışmalı ölçümü } \\
\text { söz konusudur }\end{array}$ & $\begin{array}{c}\text { Finansal performansın esasen ölçülebilir } \\
\text { kıstasları söz konusudur }\end{array}$ \\
\hline Tanımlanmış politik yönergeler vardır. & Politikalardaki belirsizlik azdır. \\
\hline
\end{tabular}

Kaynak: Macmillan and Tampoe, 2000: 51.

Tablo-1 incelendiğinde vergi planlamasının yapılmasında kanuni düzenlemeler, ulusal ihtiyaçlar, şeffaflık, kamuya yönelik olma, sosyal odaklı amaç, finansman aracı olmak, siyasi iradeye karşı sorumluluk, nitel olarak kendini hissettirmek ve planlamada kanunlara karşı sorumlu olmak gibi olgular yer almaktadır. Bu olgular ise vergileme ilkeleri ile somut özellik kazanabilecek bir duruma gelebilmektedirler.

Benzer şartlarda benzer vergi yükümlülüklerine vergi kanunları önünde tabi olunması vergilendirmede eşitlik olarak kabul edilmektedir (Kırbaş, 2006: 12). Dolayısıyla vergi planlamasında mükelleflerin içinde bulunduğu ekonomik koşullar dikkate alınmalıdır.

Hukuk toplumsal ihtiyaçları biçimsel olarak düzenlemektedir. Bununla birlikte bu biçimsel düzenleme yeterli görülmemekte, adalete ilişkin duygu ve düşüncelerin de hukuk içerisinde yer alması gerektiği ifade edilmektedir. $\mathrm{Bu}$ bakımdan adalet bir hukuk sisteminin düşünce boyutunu meydana getirir (Bilge, 1996: 18). Vergilendirmede adalet ilkesi açısından hukuk kavramına yaklaşıldığ takdirde, mükelleflerin mali güçlerine göre vergi alınması, vergi kaçakçıllğı ile çifte vergilendirmenin önlenmesi, sermaye birikimine veya reel gelir artışına engel olunmaması, emek ve sermaye faktörlerinin farklı vergilendirilmesi, en az geçim indirimi uygulanması, günün koşullarına uygun olarak vergilendirme yapılması vergilendirmede adalet ilkesinin ortaya çıkmasına yardımcı olmaktadır (Orhaner, 2007: 164-165). Bu perspektiften bakıldığında vergi planlamasının adalet olgusunu içerecek bir şekilde yapılması gerektiği ortaya konulabilir.

Vergilendirmede kesinlik ve belirlilik ilkelerine bakıldığında ise, mükellefin ödeyeceği vergi miktarının kesin, ödeme şeklinin ve zamanının herkes için açık ve belirgin olması vergilendirmede kesinlik olarak ortaya çıkarken; vergilemeye ilişkin işlemlerin keyfi olmaması vergilendirmede belirlilik ilkesi olarak ortaya çıkmaktadır (Saraçoğlu vd., 2014: 125).

Kurumlar vergisi üzerinde yapılacak değişiklikler çeşitli sonuçlar ortaya çıkarabilir. Bu sonuçlar kurumlar vergisine ilişkin literatür kapsamında aşağıdaki gibi değerlendirilebilir: 
- Arz yönlü iktisat yaklaşımının benimsediği vergi indirimi hususunun kurumlar vergisine uygulanması neticesinde uygulamanın etkinliği açısından mükelleflerin sosyo-ekonomik, kültürel ve siyasal koşullarının ülke koşullarıyla bağdaşması, ülkenin sahip olduğu gerçeklerle kurumlar vergisi indiriminin uyumlu olması, devlet ve toplum arasındaki ilişki bir güven esasına dayanmalı ve vergi politikası ile sonuçların öngörülebilir olması gereklidir (Armağan, 2007: 250).

- Şirketlerin vergi yüklerinin ülkeden ülkeye farklılık göstermesi ve bunun neticesinde düşük vergi yükünün olduğu şirketin vergi rekabetine sahip olması Avrupa Birliği'ni "Eylem Kodu” isimli bir vergi reformu yapmaya itmiş; ancak bu da yeterli olmamış ve bu konuda Birlik halen bir arayış içindedir (Bozkurt, 2006: 105-106).

- Kurumlar vergisine ilişkin muafiyetler ve istisnalar birer vergi harcamas1 niteliğinde olduğundan, bu vergi harcamalarına ilişkin yapılacak bütçe ve analizle bir vergi reformu oluşturulursa, kamuoyu ve meclis denetimi daha etkin olacaktır (Ferhatoğlu, 2005: 92).

- Vergi kanunlarının geriye doğru yürüdüğ̈̈; bir başka ifadeyle hukuki öngörülebilirliğin olmadığı bir durumda kurumlar vergisinde yapılacak bir indirim devlete olan güven sarsılacak, geleceğe dair kararlar olumsuz olarak etkilenecek, vergi uyumunu gerçekleştiren mükellefleri ekonomik ve psikolojik olarak etkileyecek, haksiz rekabet avantajı sağlayacak ve vergi adaletinden uzaklaşılmasına neden olacaktır (Aktan ve Gencel, 2003: 19).

Tablo 2. Gelir ve Kurumlar Vergisinin Vergi Gelirleri İçindeki Payı

\begin{tabular}{|c|c|c|}
\hline Yıllar & Gelir Vergisi (\%) & Kurumlar Vergisi (\%) \\
\hline 1988 & 33.7 & 14.9 \\
\hline 1989 & 38.6 & 14.1 \\
\hline 1990 & 41.0 & 10.2 \\
\hline 1991 & 42.4 & 9.0 \\
\hline 1992 & 42.4 & 7.1 \\
\hline 1993 & 40.4 & 7.2 \\
\hline 1994 & 30.9 & 7.5 \\
\hline 1995 & 30.4 & 9.5 \\
\hline 1996 & 30.1 & 8.4 \\
\hline 1997 & 31.6 & 8.3 \\
\hline 1998 & 37.7 & 8.1 \\
\hline 1999 & 33.3 & 10.5 \\
\hline 2000 & 23.4 & 8.9 \\
\hline 2001 & 29.1 & 9.3 \\
\hline 2002 & 23.0 & 9.3 \\
\hline 2003 & 20.2 & 10.3 \\
\hline 2004 & 19.5 & 9.5 \\
\hline 2005 & 20.3 & 10.3 \\
\hline 2006 & 21.0 & 8.2 \\
\hline 2007 & 22.2 & 9.2 \\
\hline
\end{tabular}


A. Burhan Bahçe \& Ö. Gümüş / Vergi Planlaması Temelinde Kamu Yararı: Kurumlar Vergisi Üzerine Teorik Bir Yaklaşım

\begin{tabular}{|c|c|c|}
\hline 2008 & 23.4 & 9.8 \\
\hline 2009 & 23.4 & 10.5 \\
\hline 2010 & 21.0 & 9.7 \\
\hline 2011 & 21.0 & 10.3 \\
\hline 2012 & 22.0 & 10.1 \\
\hline 2013 & 21.4 & 8.6 \\
\hline 2014 & 22.7 & 8.8 \\
\hline 2015 & 22.7 & 8.0 \\
\hline
\end{tabular}

Kaynak:http://www.gib.gov.tr/sites/default/files/fileadmin/user_upload/VI/CVI/Tablo_65.xls.htm (Erişim Tarihi: 02.04.2016).

Kurumlar vergisi gelirlerinin vergi gelirleri içindeki payı yıllar itibarıla azalma göstermiştir. 2006 y1lından itibaren \% 20'ye düşürülen kurumlar vergisi bu açıdan incelendiğinde vergilendirilebilir kapasiteye sahip bir kamu gelir kaynağı durumundadır. Bu vergi kapasitesini iki şekilde kullanmak mümkündür: Birinci kullanım bireylerin harcanabilir gelirinin kurumlar vergisinden elde edilecek gelir transferi ile arttırılması, ikinci yol ise buradan elde edilecek gelirlerin kamu hizmetinde kullanılmasıdır. Her iki kullanım şekli de bir nevi kamu hizmeti olarak sayılabilir. Bu noktada kurumlar vergisi ile gelir vergisi arasında bir (değiş-tokuş) söz konusudur. Bir başka deyiş̧le gelir vergisi düşürülürken, kurumlar vergisinin yükseltilmesi neticesinde ortaya çıkacak marjinal politik fayda ve marjinal politik maliyetlerin incelenmesi gerekmektedir.

\section{Grafik 6. Politik Dengede Vergi Yapısı}

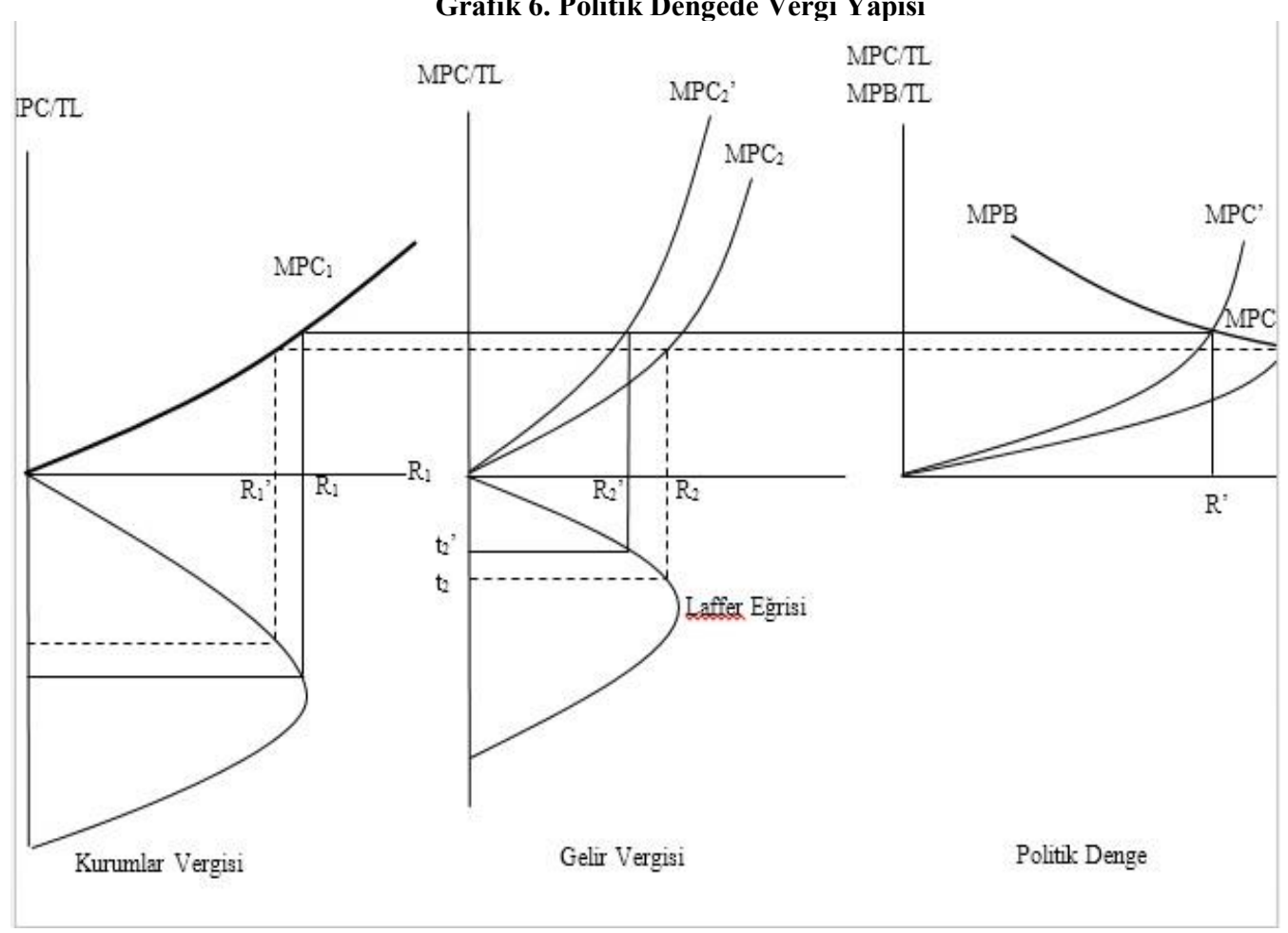

Kaynak: Hettich and Winer, 2002: 108'den esinlenerek tarafımızca çizilmiştir. 
Şekilde kurumlar vergisinin yükseltildiği buna karşılık gelir vergisinin düşürüldüğü bir durum gösterilmiştir. Kurumlar vergisinin yükselmesi ve gelir vergisinin düşürülmesi marjinal politik maliyeti düşürmekte ve marjinal politik faydayı azaltmaktadır. Buna karşılık toplam kamu geliri azalmaktadır. Bu durum ise politik bir muhalefet oluşturabilme potansiyeline sahiptir. Ancak bütçe gelirlerinin azalması ile bazı kamusal hizmetlerin işletmelere aktarılması kurumlar vergisinin yükseltilmesi neticesinde doğacak tepkinin önüne geçilebilmesini sağlayabilecektir. Böylelikle hem işletmeler hem de toplum, kamu yararı bakımından istenilen noktaya devlet tarafindan getirilmiş olur.

\section{SONUC}

Devlet özel işletmelerin ekonomik ortamda rahat hareket edebilmesi yönünde çeşitli inisiyatifler kullanmaktadır. Bu inisiyatifler kanunlarla da devlet tarafından garanti altına alınmıştır. Ancak kurumlar vergisi oranının \% 20 veya daha aşağı olması yönündeki fiiller iktisadi etkinliği, eşitlik ve adalet ilkelerini zedeleme yönündeki bir potansiyele sahip olacaktır. Dolayısıyla devlet işletmelerin koruma prensibini çok yoğun bir şekilde uygulamalarını engellemek durumundadır. Ayrıca kurumlar vergisinde istihdamı arttırmak için yapılacak bir indirim vergilemede adalet ilkesine aykırı bir durum oluşturacaktır. Özellikle geriye doğru yürüyecek bir indirim hukuki öngörülebilirlik ilkesini zedeleyecek; böylelikle hukuk devleti ilkesi zedelenmiş olacaktır. Ayrıca söz konusu indirim bireylerin ekonomik koşullarının kötü olduğu bir durumda gelir eşitliği konusunda problemler ortaya çıkacaktır.

Bunun yerine işletmelerin uyum prensibini harekete geçirecek bir şekilde vergi planlamasını yapması gerekecektir. Böyle bir durumda devlet politik bir muhalefetle karşılaşabilecektir. Ancak gelir vergisi mükellefi sayıca kurumlar vergisi mükelleflerinden daha fazladır. Böyle bir muhalefetle karşılaşılması halinde bile siyasi iktidar oy bakımından maksimizasyon yapabilecek bir durumdadır. Kaldı ki toplam kamu geliri azalacağ 1 için devletin sunduğu hizmetlerin kısmen de özel sektöre devri mümkün olacaktır.

Kurumlar vergisinde yapılacak bir indirim vergi harcaması niteliğinde olacağından etkinlik ve verimlilik denetiminin yapılması gerekecektir. Ancak yapılacak vergi harcamasının kamuoyunca denetlenebileceği gerçeğinden hareketle, ciddi bir tepki ortaya çıkacağı aşikardır. Bu durumda iktidar partisi veya iktidarı oluşturan koalisyon gerekli denetimin ortaya çıkmasını engelleyebilir. Böyle bir durum da tepkiye neden olur ve partilerin oy maksimizasyonu ilkesine ters bir durum meydana getirmektedir. Dolayısıyla devletin bu konuda daha sosyal bir şekilde hareket etmesi gerekir. Ancak bu sosyal hareketin ülkeler arasındaki vergi yükleri bağlamında şirketlere bir engel olması da engellenmelidir. Bir diğer ifadeyle vergi yükü düşük olan şirketler bu avantajdan faydalanarak uluslararası ticarette yerli şirketlere bir dezavantaj oluşturmaktadır. Bu bağlamda kurumlar vergisinin arttırıldığı bir durumda gereğinden fazla yapılan bir artış yerli şirketlerin üretim fonksiyonlarında bir gerilemeye neden olur. Dolayısıyla kurumlar vergisinde yapılacak artışın da dengeli olması sağlanmalıdır. 
Vergi planlamasında devletin dikkat etmesi gereken diğer bir husus vergilemede eşitlik, adalet ilkeleri ile kesinlik ve belirlilik ilkelerinin gözetilmesidir. Kurumlar vergisi oranının yükseltilmesi ile gelir vergisi oranının düşürülmesinden mutlak bir eşitlik olması gerektiği anlaşılmamalı; aksine söz konusu iki aktörün vergi kapasitelerine göre vergilendirilme gerekliliği ortaya çıkmaktadır. Kesinlik ve belirlilik ilkesinde ise vergilendirilecek işletmenin vergi tarhında, tebliğinde, tahakkukunda ve tahsilinde olabildiğince açık olması gerektiği ifade edilmektedir. Keza kesinlik ve belirlilik ilkelerinin vergi planlamasında açık bir şekilde yapılması kamu gelirlerinin geleceğe yönelik projeksiyonunun yapılmasına olanak taniyacaktır.

Son olarak, vergi planlamasında dikkat edilmesi gereken diğer bir husus ise iktisadi etkinliktir. Bu noktada yapılacak planlamanın işletmeler açısından mümkün olduğunca esnek olmayan bir arz eğrisine yönelik ekonomik faaliyetler olması gerekmektedir. Keza esnek bir arz eğrisine sebebiyet verecek faaliyetler toplumsal refahın ve dolayısıyla kamu yararının ortadan kalkmasına neden olacaktır. Bu bağlamda vergi planlamasının temelinde vergilemede adalet, eşitlik, kesinlik ve belirlilik ilkeleri ile iktisadi etkinliğin sağlanması hususu kamu yararı bakımından hayati bir önem taşımaktadır.

\section{KAYNAKÇA}

Agell, J., Englund, P. and Sodersten, J., (1998). Incentives and Redistribution in the Welfare StateThe Swedish Tax Reform. New York: St. Martin's Press.

Aktan, C. C. ve Gencel, U. (2003). Türkiye'de Geriye Doğru Vergileme ve Verginin Hukukiliği İlkesinin İhlali. Dokuz Eylül Üniversitesi Sosyal Bilimler Enstitüsü Dergisi, 1, 1-21.

Akyılmaz, B., Sezginer, M. ve Kaya, C. (2012). Türk İdare Hukuku. (3. Bask1). Ankara: Seçkin Yayıncilik.

Altay, A. (2015). Kamu Maliyesi. Ankara: Seçkin Yayıncılık.

Armağan, R. (2007). Türkiye'de Gelir ve Kurumlar Vergisi Oranlarında İndirimin Vergi Gelirleri Üzerine Etkileri. Süleyman Demirel Üniversitesi İ̈BF Dergisi, 3, 227-252.

Atay, E. E. (2014). İdare Hukuku. (4. Bas1). Ankara: Turhan Kitabevi.

Bildirici, Z. (1986). Ticari İşletmelerin Hukuki Yapısı Üzerinde Vergilerin Etkileri. Eskişehir: T.C. Anadolu Üniversitesi Yayınları No: 177/İktisadi ve İdari Bilimler Fakültesi Yayınları No: 41.

Bilge, N. (1996). Hukukun Başlangıcı. (11. Bask1). Ankara: Turhan Kitabevi.

Bozkurt, B. L. (2006). Avrupa Birliği'nde Kurumlar Vergisi. Maliye Dergisi, 150, 90-106.

Çomaklı, Ş. E. ve Ak, A. (2013). Vergi Ceza Hukukunda Suç ve Kabahatler. Erzurum: Erzurum Barosu.

Devrim, F. (2002). Kamu Maliyesine Giriş. İzmir: İlkem Ofset.

Doğanay, Ü. (1974). Toplum Yararı ve Kamu Yararı Kavramları, Mimarlık, 12 (7), 5-6, https://wiki.zirve.edu.tr/sandbox/users/alptekin.aktalay/weblog/bede2/attachments/eed3e/ Kamu\%20yarar1\%20mimarl1k\%20dergisi.pdf?sessionID=190148cd32475de0a28dc580d6 6c590be4060236 (Erişim Tarihi: 28.03.2016).

Erdem, M., Şenyüz, D. ve Tatlığlu, İ., (2012). Kamu Maliyesi. (10. Baskı). Bursa: Ekin Basım Yayın Dağıtım.

Eroğlu, O. (2014). Vergi Planlaması. Bursa: Ekin Basım Yayın Dağıtım.

Ferhatoğlu, E. (2005). Bir Kamu Harcaması Türü Olarak Vergi Harcaması ve Türk Kurumlar Vergisi Açısından Değerlendirilmesi. Eskişehir Osmangazi Üniversitesi Sosyal Bilimler Dergisi, 2, 77-93. 
Fevurly, K. R. (2013). Plan Your Financial Future- A Comprehensive Guidebook to Growing Your Net Worth, http://link.springer.com/book/10.1007\%2F978-1-4302-6065-3 (Erişim Tarihi: 10.03.2016).

Gao, X., Du, M. and Yang, L., (2011), Study on Applying of Tax Planning in Enterprise, Information and Management Engineering International Conference, 17-18 September, China, Wuhan: Springer-Verlag Berlin Heidelberg.

Giritli, İ., Bilgen, P., Akgüner, T. ve Berk, K. (2012). İdare Hukuku. (5. Bask1). İstanbul: DER Yayınları.

Gözler, K. (2003). İdare Hukuku. Cilt I. Bursa: Ekin Basım Yayın Dağıtım.

Gözler, K. (2011). Idare Hukukuna Giriş. (13. Baskı). Bursa: Ekin Basım Yayın Dağıtım.

Gözübüyük, A. Ş. (2007). Yönetim Hukuku. (25. Bası). Ankara: Turhan Kitabevi.

Gravelle, J. and Maguire, S. (2007). Estate Taxes and Family Businesses. Brian L. Yoshov (Ed.). Economic Issues, Taxation and Tax Policy Issues içinde (s.83-102), New York: Nova Science Publishers.

Günday, M. (2011). İdare Hukuku, (10. Bask1), Ankara: İmaj Yayınevi.

Hettich, W. and Winer, S. L. (2002). Public Choices and Fiscal Means: Analyzing Taxes as Collective Outcomes. Donald P. Racheter \& Richard E. Wagner (Ed.). Politics, Taxation and the Rule of Law- The Power to Tax Constitutional Perspective içinde (s.101-121), Massachusetts: Kluwer Academic Publishers.

Infanti, A. C. (2009). Tax Equity, Anthony C. Infanti \& Bridget J. Crawford (Ed.). Critical Tax Theory içinde (s. 60-64), USA: Cambridge University Press.

Kırbaş, S. (2006). Vergi Hukuku. (17. Bask1). Ankara: Siyasal Kitabevi.

Macmillan, H. and Tampoe, M. (2000). Strategic Management, New York: Oxford University Press. Mankiw, G., (2008). Principles of Economics. (5. Bask1). Canada: South Western Cengage Learning. Oliver, P. D., (2004). Tax Policy-Readings and Materials. (2. Baskı). New York: Foundation Press. Orhaner, E. (2007). Kamu Maliyesi. Ankara: Siyasal Kitabevi.

Parkin, M. (2010). Economics. (9. Bask1). Boston: Pearson Addison Wesley.

Perloff, J. M. (2007). Microeconomics. (4. Bask1). Boston: Pearson Addison Wesley.

Peter, V. M., Kerr, I. A. and Thorpe, M. (2002). Tax Policy in India, Asian Journal of Public Administration, 24(1), 111-138.

Ricardo, D., (1996). Principals of Political Economy and Taxation. New York: Prometheus Books.

Sancakdar, O. (2012). İdare Hukuku. (2. Baskı). Ankara: Seçkin Yayıncılık.

Saraçoğlu, F. (2014). Anayasa Mahkemesinin Vergiye İlişkin Kararlarında Kamu Yararı. Ankara: Seçkin Yayıncılık.

Saraçoğlu, F., Engin, İ ve Ejder, H. L. (2014). Maliye Ders Notları. Ankara: Gazi Kitabevi.

Şenyüz, D., Yüce, M. ve Gerçek, A., (2012). Vergi Hukuku. (3. Baskı). Bursa: Ekin Basım Yayın Dağıtım.

Şişman, B. (2003). İşletmelerde Vergi Planlaması Yöntemleri. Ankara: Yaklaşım Yayınları.

Yıldırım, R., (2015). Kamu Hizmetleri. Mustafa Avcı (Ed.). İdare Hukukuna Giriş içinde (s. 126-145), Eskişehir: T. C. Anadolu Üniversitesi Yayını No: 2466/Açıköğretim Fakültesi Yayını No: 1437.

Yıldırım, T., Yasin, M., Karan, N., Özdemir, H. E., Üstün, G. ve Tekinsoy, O. (2012). İdare Hukuku. (4. Bask1). İstanbul: On İki Levha Yayıncılık.

http://www.gib.gov.tr/sites/default/files/fileadmin/user_upload/VI/CVI/Tablo_65.xls.htm (Erişim Tarihi: 02.04.2016). 


\section{SUMMARY}

Tax is a public income and to provide efficient allocation of this kind of public income, it is necessary that tax incomes should be allocated relevantly. In this study, tax planning and its actors are examined to shed light on this aim. Tax planning has three actors: States, individuals and businesses. Every agent follows their interests and these interests should not conflict from one another.

States are accepted as the most powerful actor within these actors. As a most powerful actor, states plan every economic and fiscal event. One of this event is tax. States can affect individuals's and households'well-being by using tax. For instance, if a state levies a new tax or increases the rate of existing taxes, their wellbeing can detriorate. However,if this state can decrease the rates of existing taxes, whilst the well-being of individuals and households increases, the public income and thereby public goods and services decreases. That's why, a state can plan the public income coming from the collection of taxes carefully.

The second actor is individuals. Generally, individuals try to avoid paying taxes. For this, sometimes they can make illegal transactions. But, in this case, the state cannot collect taxes and cannot supply public goods and services. However, if the state should make an effective tax planning, no one needs to make illegal transactions on tax. Hence, tax planning is critical for such kind of situations. Otherwise, political upheavels can occur and individuals can live in a dangerous environment.

The third actor is households. Household reate employment and produce goods and services. By this way, they contribute to economy. Nevertheless, households also have to pay taxes to stat efor public interest. But his tax should be planned in a logical manner. Because tax is accepted as cost for a business, tax rates should be decreases as much as possible. But, if this decrease can be under the critical value, dead weight loss can occur and well-being of society can be damaged. To avoid this situation, there must be a common point which these three actors can negotiate.this common point can be determined by tax planning. In other words, these three actors are in a relation that can affect the economy

These relations are examined in second section and third section. At the same time, public interest is important. So, this interest can be examined into two areas: Public interest in terms of economics and public interest in terms of law. Tax planning and public interest affect taxation principles. By this way, society can be reached welfare or not. To determine this, taxation principles should be examined theoretically. Consequently, in this study, a deduction in income taxes and an increase in corporate taxes are compared within the scope of Turkish tax system. 